\title{
КОНКУРЕНТОСПОСОБНОСТЬ СЕЛЬСКИХ ТЕРРИТОРИЙ: ПРОБЛЕМЫ И ПЕРСПЕКТИВЫ *
}

\author{
(c) 2019 Потехина Елена Николаевна \\ кандидат экономических наук, доцент \\ Марийский государственный университет, Россия, Йошкар-Ола \\ E-mail: vilor@mail.ru
}

Устойчивое развитие конкурентоспособности региона во многом зависит от развития сельских территорий, как основы экономикой и социальной безопасности благосостояния жителей села и приоритетного направления конкурентоспособности сельскохозяйственного производства обеспечивающих продовольственную безопасность.

Ключевые слова: конкурентоспособность, сельские поселения, логистика, крестьянские фермерские хозяйства.

В России насчитывается более 150 тысяч сельских населенных пунктов. Проживает в них 38 миллионов человек. Деревенским жителям в нашей стране является каждый четвертый. Сельское население России - основа устойчивого развития агропромышленного комплекса. Развитие агропромышленного комплекса, имеет стратегическое значение в социальноэкономическом развитии Республики Марий Эл, обеспечивая занятость сельского населения.

В валовом региональном продукте удельный вес сельского хозяйства составляет примерно $20 \%$, в сельской местности проживает более $30 \%$ населения республики.

Болеем 50\% производимой продукции республики приходится на сельскохозяйственные предприятиях.

Республика находится в зоне рискованного земледелия и неблагоприятные погодные условия влияют на снижение объемов производства продукции растениеводства.

Исторически в республики развивали животноводство и занимались выращиванием фуражных культур.

B республике в рамках Государственной программы развития сельского хозяйства осуществляется грантовая поддержка начинающих фермеров, семейных ферм, семейных животноводческих ферм, сельскохозяйственных кооперативов. Реализация данной программы невозможно без развития личных подсобных хозяйств.

Развитие сельского хозяйства в республике зависят от ряда проблем:

- воспроизводством оборотных средств сельскохозяйственных товаропроизводителей, их недостаток приводит к несвоевременному и неполному выполнению работ;

- с особенностями кредитования, связанными с сезонностью, с зависимостью от урожайности от климатических условий, длительностью окупаемости инвестиций, спецификой залогового механизма, высокой трудозатратностью;

- технико-технологическим отставание в отрасли, вызванное урбанизацией, недостаточным использованием роботизации, селекции и биотехнологий, связанных с низкой рентабельностью и закредитованностью сельскохозяйственных производств;

- несовершенство транспортно-логистической инфраструктуры, связанные с отставанием технологии выращивания и уборки продукции; моральным и физическим износом основных средств, большой расход топлива, высокие энергозатраты, неэффективные способы хранения, сортировки и транспортировки, многоуровневая система доставки до конечного потребителя;

- крестьянские фермерские хозяйства, самостоятельно занимающиеся сбытом продукции, теряют эффект масштаба в связи с высокими расходами на доставку, составляющими значительную долю в себестоимости продукции;

- возрастающая монополизация торговых сетей, аккумулирующих большую часть торговой наценки и навязывающие жесткие для сельскохозяйственных товаропроизводителей,

\footnotetext{
" Исследования поддержаны грантом РФФИ 19-410-120005 р_а «Оценка перспектив развития сельских территорий Республики Марий Эл за счет развития несельскохозяйственных видов деятельности»
} 
связанных с увеличением срока годности, скидками, объемами партий, возвратом;

- с ростом цен на приобретаемые материально-технические ресурсы и энергоносители;

- оттоком трудоспособного населения, недостатком квалифицированного персонала на селе; привлечение молодых кадров возможно при комплексном решении, основанном на доступности социальной поддержке и сформированной доступной среды: аптеки, больницы, магазины, школы, детские сады организованный досуг в виде кинотеатров, кафе и библиотек. Молодежь, особенно IT-специалисты нуждаются для нейтрализации негативных последствий совей профессиональной деятельности, предпочитают формальную свободу, основанную на экологически чистых условиях: чистый воздух, натуральные и свежие продукты;

В программе стратегического развития республики предполагается следующие направления и механизмы:

- создание благоприятного инвестиционного климата в агропромышленном комплексе с целью производства конкурентоспособной племенной продукции животноводства в рамках приоритетного проекта «Развитие молочного скотоводства в Республике Марий Эл» по строительству, реконструкции и модернизации молочных ферм и комплексов в целях сохранения и увеличения поголовья крупного рогатого скота;

- реализация мер господдержки сельскохозяйственным предприятиям, крестьянским (фермерским) хозяйствам и предоставление грантовой поддержки;

- обеспечение финансовой устойчивости сельскохозяйственных товаропроизводителей агропромышленного комплекса путем реализации комплекса мер, направленных на повышение эффективности сельскохозяйственного производства;

- обеспечение выполнения Доктрины продовольственной безопасности Российской Федерации, утвержденной Указом Президента Российской Федерации от 30 января 2010 г. N120, в сфере производства сельскохозяйственной продукции.

В результате реализации стратегических направлений развития агропромышленного комплекса Республики Марий Эл в 2030 году планируется прирост производства продукции сельского хозяйства к уровню 2011 года составит 77,7\%.
В настоящее время 36\% площадей земель сельскохозяйственных угодий являются неиспользуемыми, в связи с длительной не обработкой участков, заросших древесной кустарниковой растительностью. В рамках федеральных программ предстоит не только вернуть земли в сельскохозяйственный оборот, но и привести их в надлежавшее состояние для пригодное для использования по назначению. При этом сельские поселения не могут в настоящее время самостоятельно возделывать земли и одним из возможных эффективных способов их использования считают сдачу их в аренду.

Развитие экономического потенциала является важнейшей стратегической целью государственной политики региона. Сельские территории претерпели в своем развитии множество трансформаций и имеют многолетнюю историю с культурно-этническими и национальными корнями, природно-климатическими и демографическими особенностями. Социальноэкономический потенциал сельских территорий необходимо развивать с учетом востребованного экологического тренда, задействую возможности модернизации и инновационного развития.

Республика богата лесными и природно-заповедными угодьями, национальной культурой, при этом активно развивается и показывает быстрый рост IT-сфера. Необходимо использовать данный потенциал интегрировать его в рамках развития сельских поселений как эффективный уклад развития экономик региона. Региональные центры инновационного развития являются способом обеспечить устранение технического и технологического отставания в сельском хозяйстве и привести к расширению местного производства в сельских поселениях.

Преодоление бедности, повышение качества жизни, решение транспортных проблем, развитие социальной инфраструктуры должно стать драйвером эффективного развития сельских поселений, малых деревень и будет способствовать сохранению и преумножению конкурентных преимуществ агропромышленного комплекса России.

Как показывает мировая практика, наиболее эффективный подход соединяет использование инструментов поддержки «прямого действия», обеспечивающих быстрый эффект и формирование благоприятных условий для экономического роста (таблица). 
Инструменты и опыт развития сельскохозяйственных поселений

\begin{tabular}{|c|c|}
\hline Инструменты прямого действия & Условия инноваций \\
\hline $\begin{array}{l}\text { - Развитая инфраструктура агропромышленного } \\
\text { комплекса (сельскохозяйственное производство и } \\
\text { переработка) } \\
\text { - Привлечение инвестиций } \\
\text { - Обеспеченность кадрами } \\
\text { - Туризм и другие альтернативные виды занятости } \\
\text { на селе }\end{array}$ & $\begin{array}{l}\text { - Развитие малого предпринимательства, личных } \\
\text { подсобных хозяйств, крестьянских фермерских } \\
\text { хозяйств) } \\
\text { - Социальная инфраструктура (школы, садики, } \\
\text { больницы, клубы) } \\
\text { - Использование региональных программ развития } \\
\text { - Государственно- частное партнерство } \\
\text { - Градовая поддержка } \\
\text { - Социальное строительство } \\
\text { - Проведение тематических фестивалей, форумов } \\
\text { - Развитие народного промысла }\end{array}$ \\
\hline \multicolumn{2}{|c|}{$\begin{array}{l}\text { Привлечение фермеров и предпринимателей } \\
\text { Расширение существующих производств } \\
\text { ние конкурентоспособного инновационного бизнеса }\end{array}$} \\
\hline Экономический результат & Прочие результаты \\
\hline $\begin{array}{l}\text { - Новые рабочие места, новые производства } \\
\text { - Рост уровня и качества жизни }\end{array}$ & $\begin{array}{l}\text { - Решение социальных проблем } \\
\text { - Рост гражданской и социальной ответственности } \\
\text { - Улучшение окружающей среды }\end{array}$ \\
\hline
\end{tabular}

Развитие цифровых технологий, расширение импорта продовольствия, является огромным стимулом для развития национального сельского хозяйства, при этом сельским поселениям необходимо найти свое место в быстроменяющихся реалиях и стать основой продовольственной и экономической безопасности, обеспечить достойный уровень жизни населения.

Развития сельских поселений основывается на комплексном подходе, при комплексном на развитие агропромышленного комплекса с одной стороны и развитии туризма и ремесленничества с другой. Развитие фермерских гостевых домов в разрезе агротуристического объединения является одной из форм реализации государственно частного партнерства в сельских поселениях. Агрохолдинги самостоятельно формируют полную цепочку от производителя, переработки, до реализации конечному потребителю. Интеграция в эту систему небольших предприятий, имеющих узкую специализацию, производящих сельскохозяйственную продукцию, занимающихся переработкой, хранением и транспортировкой, позволит эффективно развиваться небольшим предприятиям и расширить возможности развития сельских территорий. Реформы связанные с ликвидацией или реорганизацией существующих государственный и муниципальных предприятий в конкурентоспособных отраслях, а также зачастую их экономическая эффективность, укрупнения в здравоохранении, образовании приводит еще к большей актуальности грамотно выстроенной логистической инфраструктуре для развития сельских территорий. Ликвидация государственных предприятий перевозки пассажиров также является проблемой сельских территорий. Использование инновационных механизмов для транспортировки товаров, работ, услуг, организация перевозки пассажиров является приоритетной задачей. Косвенные затраты в поставках продукции сельскохозяйственного назначения, превышают 40\%. Средние логистические расходы по разным данным составляют от $15 \%$ до $20 \%$. Таким образом, логистика потенциально может снизить их в два раза.

Ключевую роль в развитии сельских населенных пунктов должны играть местные органы власти. Без их инициативы, знаний местной специфики, желания улучшить жизнь своего села или района успешное развитие невозможно. Важное значение имеют обмен опытом, координация усилий.

Эффективное стратегическое развития сельских поселений основывается на основные конкурентные преимущества на основе международного опыта:

1. Доступ к ресурсам. Республика Марий Эл имеет крупные запасы известкового камня, керамзитного, кирпичного сырья, известняка, используемого в качестве минеральной подкормки сельскохозяйственных животных, торфа, минеральных вод. Основным природным богатством Республики Марий Эл остается лес, общая площадь лесного фонда составляет более 1200 тыс. га или 57\% территории республики. Приме- 
ром нетипичного использования природных ресурсов является развитие в Лахемаа - крупнейший национальный парк в Эстонии, и прогулка по дощатой тропинке через болото Виру (Viru raba) земель абсолютно непригодные для хозяйственной деятельности благоустроены и идеально подходят для любителей пешего туризма.

2. История и культура. Актуальный тренд на национальные традиции малых народов востребован в Европе, Китае. Марийский народ хранит свою культуру и религию, основанную на вере в силу природы. Природно-ландшафтные памятники, используемые в качестве места проведения ритуалов называются Священными рощами. В Европе старинные усадьбы, фермы и даже замки получают свою вторую жизнь и трансформируются в экопоселения с культурным ресурсом. В Германии городские жители осваивают особенности сельского образ жизни, через традиционный труду на ферме. Нестандартным решением является возможность приобретения в магазинах фермерской продукции со специальной отметкой, которая при желании клиента позволяет побывать на ферме и своими глазами увидеть производство продукции или даже поучаствовать в процессе.

3. Расположение вблизи крупных городов или автомобильных трасс. Исторически поселения строились и развивались вдоль транспортных коридоров предусматривающее возможности эффективного роста за счет логистических возможностей. Развитие складских, инфраструктурных объектов, перерабатывающих и заготовительных комплексов способствует привлечения в сельские поселения дополнительную рабочую силу, квалифицированные кадры, что способствует развитию деревень.

4. Гуманитарный потенциал. В мировой практике используется еще один способ повышения эффективности и развитие сельских поселений, связанный с сотрудничеством с учебными заведениями разных уровней.

Основной акцент в развитие сельских поселений делается на сотрудничество с предпринимателями, развитием малого предпринимательства на селе, экотуризм, развитие культурного потенциала села.

Сельские поселения осуществляют свою деятельность в основном за счет внешних источников финансирования. Налог на доходы физических лиц, уплаченный в местный бюджет является основным, а иногда и единственным источником внутреннего самофинансирования. Развитие производств на территории сельских поселений, участие в федеральных программах развития способствует комплексному возрождению села в долгосрочной перспективе.

Детализация логистических систем в сельском хозяйстве для предприятий занимающихся животноводством, растениеводством, переработкой сельскохозяйственной продукцией и развитие личных подсобных и фермерских хозяйств позволяет более эффективно использовать преимущества организационно структурированной системы взаимосвязанных звеньев работающих в едином процессе управления материальными и сопутствующими им потоками. На уровне отдельного предприятия или сельского поселения необходимо оценивать эффективность снабжения, производства и сбыта готовой продукции, а также транспортную и инфраструктурную составляющую. Необходимо рационализировать и алгоритмизировать внутренние информационные, транспортные потоки. Основная задача связать разобщенные и разно удалённые производственные участки, сельскохозяйственные площади, административные участки в пространстве, учитывая значительные расстояния от мест проживания работников предприятий до их рабочих мест. Внутренние перевозки включают в себя доставку семян, горюче-смазочных материалов на поля, перемещение тракторов и комбайнов по полю, доставка готовой продукции на склады, доставку работников на рабочее место и обратно, доставку запасных частей и полуфабрикатов, незавершенное производство.

Особую актуальность приобретает сбыт готовой продукции при создании крестьянскофермерских хозяйств. Если каждый фермер занимается сбытом готовой продукции самостоятельно, то теряется эффект масштаба и расходы на доставку составляют значительную долю в себестоимости продукции. При разрозненной системе расходы на транспортировку значительны. Поэтому необходимо создание единой системы сбора готовой продукции от производителей и перемещение ее в места хранения или к переработчикам.

Еще одной особенностью логистики в сельском хозяйстве является то, что в основном, сельхозпредприятия является растительноживотноводческими. Поэтому животноводческие фермы получают корма от внутреннего 
поставщика, внешних поставок для этих целей может не быть. В случае пространственного рассредоточения сельскохозяйственных предприятий подобная автономия актуальна с точки зрения затрат на логистику. Отходы производства также находят применение внутри предприятия.

Логистика в сельском хозяйстве должна учитывать сезонность производств, возможность смены погоды, учитывать прогнозы погоды.

Использование логистического подхода в сельском хозяйстве может способствовать значительному снижению себестоимости сельскохозяйственной продукции, развитию отдельных хозяйств и агропромышленного комплекса России.

\section{Библиографический список}

1. Потехина Е.Н. Концептуальная модель инновационной устойчивости логистической деятельности // Инновационное развитие экономики. - 2017. - № 6(42). - С. 145-148.

2. Потехина Е.Н. Факторы инновационной устойчивости и их влияние на логистическую деятельность // Инновационное развитие экономики. - 2017. № 6(42). - С. 149-151.

3. Российская Федерация. Законы. Конституция Российской Федерации [Электронный ресурс]: принята всенародным голосование 12 декабря 1993 года (в ред. федер. Конституционных законов от 30 декабря 2008 № 6-ФКЗ и № 8 - ФКЗ) // СПС «Консультант плюс»

4. Российская Федерация. Гражданский кодекс Российской Федерации: часть первая [Электронный ресурс]: федер. закон № 51-ФЗ 30.11.94: принят ГД ФС РФ 21.10.1994: по состоянию на 07.11.2019 г. // СПС «Консультант плюс» 